\title{
Communication
}

\section{Observations on the Association between Some Buprestid and Cerambycid Beetles and Black Frankincense Resin Inducement}

\author{
Hilary Sommerlatte ${ }^{1, *}$ and Ben-Erik Van Wyk ${ }^{2}$ \\ 1 Arbor Oils of Africa, P.O. Box 24, Naro Moru 10105, Kenya \\ 2 Department of Botany and Plant Biotechnology, University of Johannesburg, P.O. Box 524, \\ Johannesburg 2006, South Africa; bevanwyk@uj.ac.za \\ * Correspondence: hilary@oilsafrica.com; Tel.: +254-714053917
}

check for updates

Citation: Sommerlatte, H.; Wyk, B.-E.V. Observations on the Association between Some Buprestid and Cerambycid Beetles and Black Frankincense Resin Inducement. Diversity 2022, 14, 58. https:// doi.org/10.3390/d14010058

Academic Editor: Luc Legal

Received: 28 December 2021

Accepted: 14 January 2022

Published: 16 January 2022

Publisher's Note: MDPI stays neutral with regard to jurisdictional claims in published maps and institutional affiliations.

Copyright: (c) 2022 by the authors. Licensee MDPI, Basel, Switzerland. This article is an open access article distributed under the terms and conditions of the Creative Commons Attribution (CC BY) license (https:// creativecommons.org/licenses/by/ $4.0 /)$.

\begin{abstract}
Samburu resin harvesters in northern Kenya maintain that frankincense resin flow from Boswellia neglecta and Commiphora confusa is induced by insect larval activity. Observations on the insects' larval behaviour support these claims. During the frankincense harvest, buprestid beetle larvae, identified as a Sphenoptera species, are found under B. neglecta resin, eating the monoterpenerich inner bark, which apparently stimulates the trees to produce copious amounts of fresh resin. The same behaviour was observed with cerambycid beetle larvae, identified as Neoplocaederus benningseni Kolbe, on $C$. confusa trees. Remarkably, these insects have developed the capacity to digest the resin-saturated inner bark and overcome the toxic, repellent characteristics of oleo-monoterpenes. The frankincense resin also appears to act as a protective covering during the insects' larval and pupal stages. Excessive tree damage was not noted from these insect invasions. Even though the tree species are from different genera, the resin produced by both is black, with a very similar aromatic chemical profile. The question thus arises as to whether the larval feeding behaviour of these beetle species has an influence, not only on the physical appearance but also on the chemical composition of the resins.
\end{abstract}

Keywords: Buprestidae larvae; Burseraceae; Cerambycidae larvae; Boswellia neglecta; Commiphora confusa; frankincense resin inducement

\section{Introduction}

There are two tree species in northern Kenya that produce monoterpenoid frankincense resins of commercial importance [1]. Boswellia neglecta S. Moore is found in areas of low rainfall on hill slopes and well-drained rocky areas and gullies, where soils are shallow, growing at elevations of 150 to $1300 \mathrm{~m}$. B. neglecta produces two types of aromatic frankincense resins. The first type consists of pale-yellow droplets, which exude spontaneously from the surface of the bark, without there being any notable damage to the bark surface. This resin is chewed by Samburu collectors, as a type of chewing gum. The second type of resin is black and resembles sticky tar. It is produced in much bigger quantities and is harvested for commercial purposes [1]. It contains $\alpha$-pinene, $\alpha$-thujene, terpinen-4-ol, $p$-cymene and $\beta$-pinene as its main volatile compounds [1]. Commiphora confusa Vollesen occurs in Acacia-Commiphora bushland on rocky slopes or quartz-strewn sandy soil over basement rocks, growing at elevations of 600 to $1300 \mathrm{~m}$. The tree produces three types of exudates. The first type is similar to that of B. neglecta, whereby pale-yellow, aromatic frankincense resin droplets exude spontaneously from the surface of the bark, without there being any notable damage to the bark's surface. This is also used as a chewing gum by Samburu collectors and is harvested and sold as frankincense. The second type is a clear, non-aromatic, polysaccharide gum produced in copious quantities when the tree branches or stems are damaged. The third type is an aromatic, black resin that is harvested and sold as frankincense [1]. It contains $\alpha$-pinene, $\alpha$-thujene, $\beta$-pinene, terpinen- 4 -ol, and $p$-cymene as major volatile constituents [1]. 
Prior to this study, it was believed that tapping, which involves making repeated incisions on the bark over several months, was the only means of frankincense resin inducement. This preliminary study is the first to investigate the possibility that insect larval chewing activity induces the flow of frankincense resin.

\section{Materials and Methods}

Field observations were made by the first author in various parts of Samburu district in northern Kenya. She collected mature beetles, cocoons and larvae in and on B. neglecta and C. confusa resins. The insect specimens were stored in $90 \%$ alcohol in $2 \mathrm{~mL}$ and $8 \mathrm{~mL}$ glass vials with screw caps and straight side walls, with an opening, the full diameter of the vial to simplify specimen insertion.

The sampling methods were opportunistic in that all frankincense trees with resin that the first author came across were investigated for the presence of beetle larvae, adults or cocoons. Table 1 presents more detailed descriptions of individual collections. Insect specimens were deposited in the National Museums of Kenya, Nairobi, as voucher specimens. Two cerambycid beetles, voucher nos: Nmk/inv-2021-001 and Nmk/inv2021-002; one cerambycid larva, voucher no: Nmk/inv-2021-003; one cerambycid cocoon, voucher no: Nmk/inv-2021-004. Three buprestid larvae, voucher nos: Nmk/inv-2021-005, Nmk/inv-2021-006 and Nmk/inv-2021-007. Some specimens were kept by the first author for future reference.

The species were identified by Mr. Morris Mutua, Senior Research Technologist, in the Entomology Department of the National Museums of Kenya, Nairobi. The cerambycid specimens were identified by comparing them to existing collections in the Museum, and the buprestid larvae were identified by the morphological characteristics of Sphenoptera larvae [2].

Table 1. Collection methods and observations on the buprestid and cerambycid insects and their association with frankincense trees in northern Kenya.

\begin{tabular}{|c|c|c|c|c|c|}
\hline Tree Species & Locality & Date & $\begin{array}{l}\text { Insect Species } \\
\text { and Stage }\end{array}$ & $\begin{array}{l}\text { Number of } \\
\text { Specimens } \\
\text { Collected }\end{array}$ & Observations \\
\hline $\begin{array}{l}\text { Boswellia } \\
\text { neglecta }\end{array}$ & $\begin{array}{l}\text { Oldonyo Mara } \\
\text { hill, South Horr. }\end{array}$ & May 2015 & $\begin{array}{l}\text { Sphenoptera sp. } \\
\text { immature larvae }\end{array}$ & 4 & $\begin{array}{l}\text { Fresh black resin was seen dripping from several } \\
\text { mature trees. When the fresh resin was peeled } \\
\text { back, in all resin samples, immature larvae were } \\
\text { found within the resin mass, eating the inner } \\
\text { bark, which was thin (ca. } 4 \text { mm thick). The } \\
\text { chewed indentations were shallow (ca. } 4 \mathrm{~mm} \\
\text { deep) and did not penetrate the heartwood } \\
\text { (Figure } 1(\mathrm{~A} 1) \text { ). Four larvae were lifted out of the } \\
\text { resin with twigs, and stored in } 2 \mathrm{~mL} \text { spirit vials. }\end{array}$ \\
\hline B. neglecta & Mathews Range. & Aug 2017 & $\begin{array}{l}\text { Sphenoptera sp. } \\
\text { mature larvae }\end{array}$ & 1 & $\begin{array}{l}\text { Fresh resin collected by Samburu collectors, } \\
\text { from the foothills of the Mathews range, was } \\
\text { delivered to the first author. During resin } \\
\text { sorting, several mature larvae were noted, } \\
\text { feeding inside the fresh resin. One larva was } \\
\text { lifted out of the resin with a twig and stored in a } \\
2 \mathrm{~mL} \text { spirit vial. }\end{array}$ \\
\hline B. neglecta & $\begin{array}{l}\text { Summit of } \\
\text { Lemogor hill, } \\
\text { Milgis. }\end{array}$ & $\begin{array}{l}\text { Feb } \\
2021\end{array}$ & $\begin{array}{c}\text { Sphenoptera sp. } \\
-\end{array}$ & - & $\begin{array}{l}\text { Aproximately } 15 \text { mature trees were examined in } \\
\text { a dense woodland of } B \text {. neglecta trees. All trees } \\
\text { had had insect infestations, indicated by healed } \\
\text { over indentations. Examined trees showed } \\
\text { complete recovery from larval chewings under } \\
\text { resin (Figure } 1(C 1, C 2) \text {. Excessive damage or tree } \\
\text { mortality was not noted from insect invasions. }\end{array}$ \\
\hline
\end{tabular}


Table 1. Cont.

\begin{tabular}{|c|c|c|c|c|c|}
\hline Tree Species & Locality & Date & $\begin{array}{l}\text { Insect Species } \\
\text { and Stage }\end{array}$ & $\begin{array}{l}\text { Number of } \\
\text { Specimens } \\
\text { Collected }\end{array}$ & Observations \\
\hline B. neglecta & $\begin{array}{l}\text { Summit of } \\
\text { Laikawa hill, } \\
\text { Milgis. }\end{array}$ & Aug 2021 & $\begin{array}{l}\text { Sphenoptera sp. } \\
\text { mature larvae }\end{array}$ & 4 & $\begin{array}{l}\text { There was a woodland of almost pure stands of } \\
\text { B. neglecta, with a mixed population of adult and } \\
\text { young trees. We examined aproximately } 12 \text { adult } \\
\text { trees and for each adult tree, there appeared to } \\
\text { be up to } 5 \text { infestations, each with a lot of resin } \\
\text { exudation. All revealed larvae under the resins. } \\
\text { One larva was found in a hole under the resin } \\
\text { (Figure } 1(\mathrm{~A} 3) \text { ) and another appeared to be } \\
\text { making a hole under the resin (Figure 1(A2)). } \\
\text { Often, we found the insects had burrowed under } \\
\text { the intact bark of the tree, which concealed both } \\
\text { the resin and the insects (Figure } 1 \text { (A4)). The trees } \\
\text { showed natural senescence with dead twigs and } \\
\text { branches, and most of the exposed dead } \\
\text { branches had insect holes and were occupied by } \\
\text { a variety of insects. Excessive damage or tree } \\
\text { mortality was not noted from insect invasions. } \\
\text { Four mature larvae specimens were collected } \\
\text { and stored in } 2 \text { mL spirit vials. }\end{array}$ \\
\hline $\begin{array}{l}\text { Commiphora } \\
\text { confusa }\end{array}$ & Sera & Oct 2014 & $\begin{array}{c}\text { Neoplocaederus } \\
\text { benningseni } \\
-\end{array}$ & - & $\begin{array}{l}\text { We examined } 240 \text { C. confusa trees in } 6 \text { different } \\
\text { locations, during a resource assessment } \\
\text { conducted by the first author. Of this popuation, } \\
\text { aproximately } 45 \% \text { were mature trees. Most of } \\
\text { these trees had bark "scabs" showing recovery } \\
\text { from shallow scrapings from goats and larval } \\
\text { activity (Figure } 1(\mathrm{C} 3, \mathrm{C} 4) \text { ). According to collector } \\
\text { information, C. confusa has very regenerative } \\
\text { properties, as any cuts or scrapings are sealed off } \\
\text { and repaired within } 4 \text { months. Tree mortality } \\
\text { was not noted from insect invasions. }\end{array}$ \\
\hline C. confusa & Sera & May 2015 & $\begin{array}{l}\text { N. benningseni } \\
\text { immature larvae }\end{array}$ & 2 & $\begin{array}{l}\text { Resin was noted on the bark of several trees. } \\
\text { Resin was gently lifted on two trees, revealing } \\
\text { larvae eating the inner bark (Figure } 1(\mathrm{~B} 1)) \text {. The } \\
\text { chewed indentations (Figure } 1(\mathrm{C} 3) \text { ) were } \\
\text { shallow (ca. } 3 \mathrm{~mm} \text { deep). The two larvae were } \\
\text { gently lifted out of the resin with twigs and put } \\
\text { into } 2 \mathrm{~mL} \text { spirit vials. }\end{array}$ \\
\hline C. confusa & Sera & May 2016 & $\begin{array}{l}\text { N. benningseni } \\
\text { immature larvae }\end{array}$ & 1 & $\begin{array}{l}\text { Resin was collected from Sera and delivered to } \\
\text { the first author. During resin sorting, several } \\
\text { immature larvae were noted feeding in the resin. } \\
\text { One immature larva was gently prised out of the } \\
\text { resin with a twig, and stored in a } 2 \mathrm{~mL} \text { spirit vial. }\end{array}$ \\
\hline C. confusa & Sera & Oct 2016 & $\begin{array}{l}\text { N. benningseni } \\
\text { mature larvae }\end{array}$ & 2 & $\begin{array}{l}\text { Resin was collected from Sera and delivered to } \\
\text { the first author. During resin sorting, several } \\
\text { mature larvae were noted feeding in the resin. } \\
\text { Two mature larvae were gently prised out of the } \\
\text { resin with a twig, and stored in } 2 \mathrm{~mL} \text { spirit vials. }\end{array}$ \\
\hline C. confusa & Sera & Oct 2016 & $\begin{array}{l}\text { N. benningseni } \\
\text { cocoon and } \\
\text { cocoon } \\
\text { fragments }\end{array}$ & 1 & $\begin{array}{l}\text { Resin was collected from Sera and delivered to } \\
\text { the first author. During resin sorting, a complete } \\
\text { cocoon made of bark strips and a shell-like } \\
\text { substance was found embedded in the resin } \\
\text { (Figure 1(B3)). Numerous cocoon fragments } \\
\text { were also found within the resin. }\end{array}$ \\
\hline C. confusa & Sera & Nov 2016 & $\begin{array}{l}\text { N. benningseni } \\
\text { mature beetles }\end{array}$ & 3 & $\begin{array}{c}\text { Resin was collected from Sera and delivered to } \\
\text { the first author. During resin sorting, three } \\
\text { beetles emerged from cocoons (Figure } 1(\mathrm{~B} 4, \mathrm{~B} 5)) \text { ). } \\
\text { These were captured and stored in } 8 \mathrm{~mL} \\
\text { spirit vials. }\end{array}$ \\
\hline
\end{tabular}




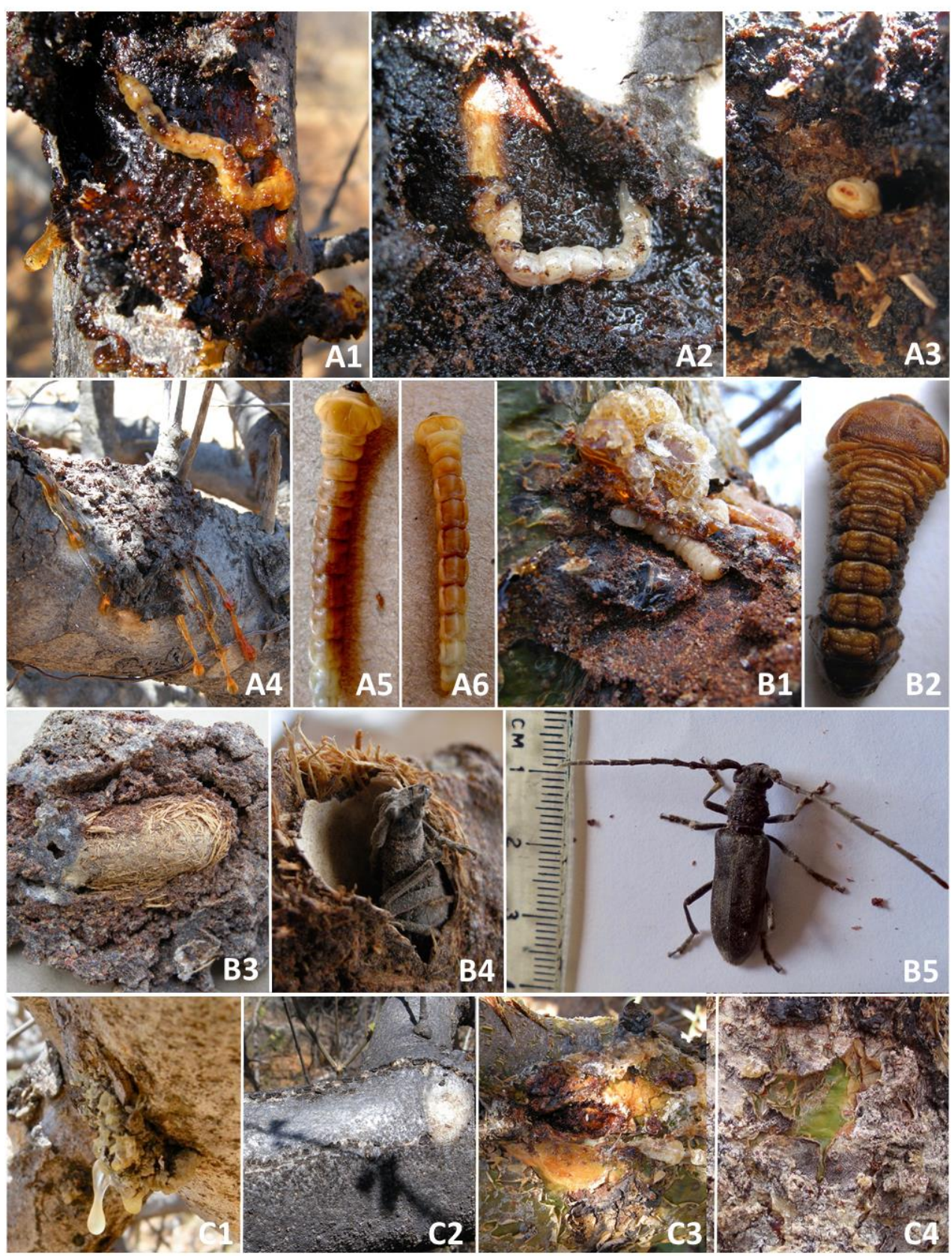

Figure 1. The buprestid and cerambycid beetles and the bark/resin of Boswellia neglecta and Commiphora confusa in northern Kenya: (A) Sphenoptera sp. larva and the bark/resin of B.neglecta: (A1) Larva eating inner bark and apparently inducing resin production (locality: Oldonyo Mara); $(\mathbf{A 2}, \mathbf{A} 3)$ Larvae making holes and preparing to pupate (Laikawa hill, Milgis); (A4) B. neglecta resin covering Sphenoptera sp. larva (Laikawa hill); (A5) Sphenoptera sp. larva, dorsal view (Laikawa hill); (A6) Sphenoptera sp. larva, ventral view (Laikawa hill); (B) Neoplocaederus benningseni and the bark/resin of C. confusa: (B1) Larva eating the inner bark and apparently inducing resin production (locality: Sera); (B2) N. benningseni larva (Sera); (B3) Larva cocoon in C. confusa resin (Sera); (B4) N. benninseni beetle hatching from cocoon in C. confusa resin; (B5) Adult N. benninseni beetle (Sera). (C) B. neglecta and C. confusa bark regeneration from bark beetle larval chewings; (C1) Wound under B. neglecta resin from Sphenoptera sp. larval chewing (Laikawa hill, Milgis); (C2) B. neglecta bark recovery from insect activity (Laikawa hill); (C3) Wound on C. confusa bark from N. benningseni larval chewing (Sera); (C4) C. confusa bark recovery from N. benningseni larval chewing (Sera). Photographs by Hilary Sommerlatte. 


\section{Results}

The buprestid beetle larva associated with B. neglecta was identified as a Sphenoptera species (Coleoptera: Buprestidae), and the cerambycid larva and adult beetle associated with C. confusa, as Neoplocaederus benningseni Kolbe (Coleoptera: Cerambycidae).

Observations of bark beetles and the resin of B. neglecta and C. confusa are summarized in Table 1 and illustrated in Figure 1.

\section{Discussion}

From the preliminary observations summarized in Table 1, it appears that, soon after the rains, around May, the larval chewings of the two beetle species along the resinsaturated inner bark, stimulated the frankincense trees to produce copious amounts of aromatic black resin (Figure 1(A1,B1)). As the Samburu collectors pointed out, under all fresh resin there will always be a larva ("worm"). At the end of the dry season, between August and October, when the larvae pupate and chewings cease, the resin dries and hardens. It is these easily collectable lumps of frankincense resin that the Samburu harvest and sell as frankincense.

The abundance of resin production caused by the presence of insect infestations has been noted in other monoterpenoid resin producing species [3]. It was reported that in conifers, the aromatic monoterpene oleoresins are used as a defence mechanism against attacking insects. The viscous, sticky resin, released in response to insect attacks, is toxic to the adults, larvae and eggs, and physically entraps the invading organisms [3].

Interestingly, the larvae of both the buprestid Sphenoptera sp. and the cerambycid $N$. benningseni appear to have developed a high degree of tolerance to the physical and toxic properties of the monoterpene resins. They eat the resin-saturated inner bark and are enveloped by the resin during several months of their larval phase. Furthermore, the resin mantle may act as a protective cover against predators during the larval and pupal stages. The fresh resin covers the vulnerable feeding larvae (Figure $1(\mathrm{~A} 4, \mathrm{~B} 1)$ ) and the dry, hard resin protect the pupae. In the latter case, the first author noted that the N. benningseni larvae make their cocoons within the dry resin of C. confusa (Figure 1(B2-B4)) and the Sphenoptera sp. larvae bore into the wood under the resin, which dries and covers the pupal hole (Figure 1(A2-A4)).

In the literature, buprestid and cerambycid species have not been mentioned to effect frankincense resin inducement in other frankincense oleoresin producing species such as Boswellia sacra Flückiger, B. papyrifera (Caill. ex Delile) Hochst., B. serrata Roxb. and B. carteri Birdw. Frankincense inducement in these species is brought about by tapping, which involves making repeated incisions in the bark over a series of months [4-6]. However, over-tapping, which involves making too deep or too many tapping spots, carried out too frequently than is traditionally practiced for sustainable harvesting, severely weakens the trees. Weakened trees are susceptible to frequent attacks by buprestid and cerambycid species [4,7]. The relationship between these insects and their frankincense tree hosts is destructive rather than sustainable and is a cause of high tree mortality [8-10]. This is causing concern about the sustainability of the frankincense resin trade from these species $[4,7,8]$.

The buprestid and cerambycid beetle larval chewings along the inner bark on B. neglecta and $C$. confusa, respectively, are shallow scrapings up to $5 \mathrm{~mm}$ deep, which soon heal over (Figure 1(C1-C4)). Excessive damage or tree mortality was not noted from these insect invasions in all the populations of B. neglecta and C. confusa visited. Therefore, the induced black frankincense resin harvest from larval chewings appears to be sustainable.

Unlike most Boswellia species, which produce a pale-yellow, clear frankincense resin as a result of tapping, the $B$. neglecta and C. confusa trees produce mainly a black, crumbly frankincense resin, apparently induced by insect activity. Interestingly, the resins of both species have a very similar aromatic chemical profile, even though the trees are from different genera [1]. Analyses of the volatile compounds of steam-distilled black resin of both species collected at several localities in Kenya [1,11,12] and Ethiopia [1,12] highlighted 
the qualitative similarity between the two species and the two countries [1]. The levels of the main compounds (as a percentage of total composition) in these studies in both Ethiopia and Kenya for B. neglecta and C. confusa were, respectively: $\alpha$-pinene (17.8-84.7; 16.3-57.1), $\beta$-pinene (1.3-13.7; 9.5-17.5), $\alpha$-thujene (8.1-19.0; 11.9-23.1), $p$-cymene (0.1-13.7; 1.2-11.7), and terpinen-4-ol (0.5-20.6; 0.8-13.7) [1]. The question arises if the feeding activities of these particular buprestid and cerambycid beetle species have an influence on the texture, colour and aromatic profile of the frankincense. Freshly exuded gum-resins are generally colourless or pale yellow and darker colours are caused by autoxidation, polymerization and enzyme activity [13]. One or more of these processes may be triggered by the insect larvae, an aspect that deserves further study.

\section{Conclusions}

The observations presented here support the claims of Samburu frankincense collectors that the Sphenoptera sp. and the $N$. benningseni beetle larval chewings are responsible for frankincense resin production in B. neglecta and C. confusa, respectively. Apparently, the larvae "act as tappers", and the copious amounts of aromatic resin produced provides a protective mantle in the vulnerable stages of the insects' life cycles. It is this insect-induced black resin which is collected from both tree species and sold as frankincense. As the trees are not weakened by undue stress from repeated tapping by collectors, the equilibrium of insect and host interactions is not disrupted, with the consequence of limited damage to the trees by insect invasions.

These relationships require further investigation and experimental evidence to elucidate the role of these beetle species in the inducement of frankincense and the effect it may have on the physical appearance and chemical composition of the resin. Such an association may also apply to commercial Burseraceae resins from other parts of the world.

Author Contributions: Conceptualization, methodology, investigation, writing-original draft preparation, H.S.; writing-review and editing, B.-E.V.W. All authors have read and agreed to the published version of the manuscript.

Funding: This research received no external funding.

Institutional Review Board Statement: Not applicable.

Informed Consent Statement: Not applicable.

Data Availability Statement: The data presented in this study are openly available in the National Museums of Kenya, voucher numbers: Nmk/inv-2021-001, Nmk/inv-2021-002, Nmk/inv-2021-003, Nmk/inv-2021-004, Nmk/inv-2021-005, Nmk/inv-2021-006 and Nmk/inv-2021-007.

Acknowledgments: The first author wishes to thank several of the registered Samburu frankincense collectors, particularly Nalangu Lemaseyo, for showing her the resin collecting areas and revealing the perceived role of bark insects. Thanks, are also due to Morris Mutua, Senior Research Technologist, Entomology Department, National Museums of Kenya, Nairobi, for identifying the insects and to Daniel Mahr, University of Wisconsin-Madison, for invaluable comments.

Conflicts of Interest: The authors declare no conflict of interest. The first author is a director of the certified organic company, Arbor Oils of Africa. Their operation buys the sustainably harvested resins from Boswellia neglecta and Commiphora confusa trees from the Samburu collectors.

\section{References}

1. Asfaw, N.; Sommerlatte, H.; Demissew, S. Uncommon Frankincense. Perfum. Flavorist 2019, 44, 46-55.

2. Pshtiwan, A.J.; Wand, K.A. Morhology of the Larva of Sphenoptera (Tropeopeltis) servistana Obenberger, 1929 (Coleoptera: Buprestidae) from Erbil, Kurdistan region, Iraq. Biologia 2021, 76, 169-177.

3. Franceschi, V.R.; Kroken, P.; Christiansen, E.; Krekling, T. Anatomical and Chemical Defenses of Conifer bark against Bark Beetles and other Pests. New Phytol. 2005, 167, 353-375. [CrossRef] [PubMed]

4. Eshete, A. The Frankincense Tree of Ethiopia: Ecology, Productivity and Population Dynamics. Ph.D. Thesis, Wageningen University, Wageningen, The Netherlands, 2011.

5. Farah, A. The Milk of the Boswellia Forests: Frankincense Production among the Pastoral Somali; Cab Direct: Oxford, UK, 1994. 
6. Sinha, S.K.; Pathak, J.G.; Mehta, A.A.; Behera, L.K. Tapping methods in Salai Guggal (Boswellia serrata Roxb.) for Sustainable Yield of Oleo-gum resin: A Case Study. Int. J. Usuf. Mngt. 2016, 17, 13-18.

7. Negussie, A.; Gebrehiwot, K.; Yohannes, M.; Norgrove, L.; Aynekulu, E. Continuous resin tapping for frankincense harvest increases susceptibility of Boswellia papyrifera (Del.) Hochst trees to longhorn beetle damage. Heliyon 2021, 7, e06250. [CrossRef]

8. De Carlo, A.; Ali, S.; Ceroni, M. Ecological and Economic Sustainability of Non-Timber Forest Products in post-Conflict Recovery: A Case Study of the Frankincense (Boswellia spp.) Resin Harvesting in Somaliland (Somalia). Sustainability 2020, $12,3578$. [CrossRef]

9. Negussie, A.; Gebrehiwot, K.; Yohannes, M.; Aynekulu, A.; Manjur, B.; Norgrove, L. An exploratory survey of long horn beetle damage on the dryland flagship tree species Boswellia papyrifera (Del.) Hochst. J. Arid Environ. 2018, 152, 6-11. [CrossRef]

10. Strumia, F.; Dapporto, L.; Dellacasa, M.; Scaramozzino, P.L. Notes on some Insects associated to Frankincense Tree Boswellia sacra Flückiger, 1867, Burseraceae, in Dhofar, Sultanate of Oman, Atti Soc. Tosc. Sci. Nat. Mem. Ser. B 2007, 114, 135-139.

11. Provan, G.J.; Gray, A.I.; Waterman, P.G. Monoterpene-rich resins from some Kenyan Burseraceae. Flavour Fragr. J. 1987, 2, 115-118. [CrossRef]

12. Dekebo, A. Chemical studies of the resins of some Boswellia and Commiphora species. Ph.D. Thesis, Addis Ababa University, Addis Ababa, Ethiopia, 2002.

13. Wagner, H.; Bauer, R. Arzneidrogen und Ihre Inhaltstoffe, 6th ed.; Wissenschaftliche Verlagsgesellschaft: Stuttgart, Germany, 1999; ISBN 3-8047-1605-9. 